\title{
JAUNDICE IN PEDIATRIC VISCERAL LEISHMANIASIS (KALA-AZAR) PATIENTS
}

\author{
AKM MAMUNUR RASHID ${ }^{1}$, ABDULLAH AL MAMUN ${ }^{2}$, C H RASUL ${ }^{3}$, MD. ASRAFUZZAMAN ${ }^{4}$, \\ MUKTER HOSSAIN $^{5}$, MD. MUJIBUR RAHMAN ${ }^{6}$
}

\begin{abstract}
Summary
Visceral leishmaniasis (Kala-azar) is endemic in many countries including Bangladesh. Clinical presentation of visceral leishmaniasis in children and adult may vary and at time may simulate many tropical and hepatobilliary diseases. Jaundice and ascites is not common in some patients. In this series of eleven cases Jaundice, splenomegaly, hepatomegaly and ascites are present in $55 \%, 100 \%, 91 \%$, 27\% of cases respectively. So, Kala-azar should be kept in mind while dealing with cases of many such clinical findings.
\end{abstract}

\section{Introduction:}

Leishmaniasis (Kala-azar) is now endemic in 88 countries with a total 350 million people at risk ${ }^{1,2}$. World wide there are estimated to be approximately $5,00,000$ cases of visceral leishmaniasis per year ${ }^{3}$. $90 \%$ of all kala-azar cases occur in Bangladesh., Brazil, India, Nepal and Sudan ${ }^{4}$. In Bangladesh the number of cases in northern district are alarmingly high ${ }^{5,6}$. Sporadic cases are found in other parts also. The disease is characterized by chronic fever, hepatosplenomegaly, emaciation and anaemia ${ }^{7,8}$. Jaundice and Ascites are rare presenting features of Kalaazar $^{9}$. The experiences in this short series are analyzed about the unusual presentation of jaundice in kala-azar patients.

\section{Patients, Methods and Results:}

All the records of the pediatrics kala-azar patients presenting with jaundice were included in this short series. Age range was between 1-12 years. The period of study was between January 2005 to May 2006. There age and sex distribution was done. Clinical presentations and investigation reports were analyzed .The diagnosis was made by serology test ICT (Immunochromatography) and Bone marrow study
Total eleven kala-azar Paediatrics patients were admitted during this period. Among them 6 (55\%) 4 girls, 2 boys with jaundice. They were between the ages of 4-10 years. In our observation, the presenting symptoms of fever, yellow discoloration of eye \& urine, loss of weight, pain in the abdomen was found in 10(91\%), 6(55\%), 3(27\%), 3(27\%) respectively. Regarding the clinical signs, anaemia of different degree and splenomegaly was observed in $11(100 \%)$, Hepatomegaly in 10(91\%), Jaundice in $6(55 \%)$, Ascites in 3(27\%) cases. Out of 6 jaundiced patients $4(67 \%)$ had hemoglobin much below normal level. ESR was high in all the patient except one who's ESR was not done. Leucopenia and relative lymphocytosis was not observed in any patients. Raised serum bilirubin was found in all the patients and SGPT was high in 5(83\%) cases. Initial clinical diagnosis of chronic liver disease (CLD) was made in $4(36 \%)$, congenital hemolytic anaemia in $1(9 \%)$ and kala-azar in rest of the patients $6(55 \%)$ out of 11.

The details of the clinical profile and investigation findings were shown in Table 1 and 2. All the cases were treated with appropriate dose and course of Sodium stibogluconate.

1. Associate Professor, Department of Paediatrics, Khulna Medical College, Khulna.

2. Associate Professor, Department of Medicine, Khulna Medical College, Khulna.

3. Professor, Department of Paediatrics, Khulna Medical College, Khulna.

4. Assistant Professor, Department of Microbiology, Khulna Medical College, Khulna.

5. Assistant Professor, Department of Pathology, Khulna Medical College, Khulna.

6. Professor, Department of Medicine, Begum Khaleda Zia Medical College 
Table-I

Kala-azar: a clinical profile

\begin{tabular}{|c|c|c|c|c|c|c|}
\hline Parameters & Case1 & Case2 & Case3 & Case4 & Case5 & Case6 \\
\hline Age & 4 Yrs & $8 Y r s$ & 10 Yrs & 9Yrs & 5 Yrs & 8 Yrs \\
\hline Sex & $\mathrm{F}$ & M & $\mathrm{F}$ & $\mathrm{F}$ & $\mathrm{F}$ & M \\
\hline \multicolumn{7}{|l|}{ Symptoms } \\
\hline Pain in the abdomen & $\mathrm{A}$ & $\mathrm{A}$ & $\mathrm{A}$ & $\mathrm{A}$ & $\mathrm{A}$ & + \\
\hline Fever & + & + & + & + & + & + \\
\hline Bleeding & $\mathrm{A}$ & $\mathrm{A}$ & $\mathrm{A}$ & $\mathrm{A}$ & $\mathrm{A}$ & $\mathrm{A}$ \\
\hline Loose motion & $\mathrm{A}$ & $\mathrm{A}$ & $\mathrm{A}$ & $\mathrm{A}$ & $\mathrm{A}$ & $\mathrm{A}$ \\
\hline Cough & $\mathrm{A}$ & A & $\mathrm{A}$ & + & $\mathrm{A}$ & $\mathrm{A}$ \\
\hline Anorexia & $\mathrm{A}$ & $\mathrm{A}$ & $\mathrm{A}$ & $\mathrm{A}$ & $\mathrm{A}$ & $\mathrm{A}$ \\
\hline Loss of weight & $\mathrm{A}$ & $\mathrm{A}$ & $\mathrm{A}$ & $\mathrm{A}$ & + & $\mathrm{A}$ \\
\hline Yellow colour of eye or urine & + & + & + & + & + & + \\
\hline \multicolumn{7}{|l|}{ Signs } \\
\hline Anaemia & + & + & + & + & + & + \\
\hline Jaundice & + & + & + & + & + & + \\
\hline Oedema & + & $\mathrm{A}$ & $\mathrm{A}$ & $\mathrm{A}$ & $\mathrm{A}$ & $\mathrm{A}$ \\
\hline Hepatomegaly & + & + & + & + & + & + \\
\hline Splenomegaly & + & + & + & + & + & + \\
\hline Ascites & + & A & $\mathrm{A}$ & $\mathrm{A}$ & $\mathrm{A}$ & $\mathrm{A}$ \\
\hline
\end{tabular}

$\mathrm{A}=\mathrm{Absent} ; \mathrm{F}=$ Female; $\mathrm{M}=\mathrm{Male} ; \mathrm{A}=$ Absent. + ( present).

Table - II

Kala-azar: investigative findings.

\begin{tabular}{lcccccc}
\hline Parameters & Case1 & Case2 & Case3 & Case4 & Case5 & Case6 \\
\hline Serum Bilirubin $(\mathrm{mg} \%)$ & 9.2 & 2.3 & 3 & 2.4 & 2.8 & 1.5 \\
SGPT & 102 & 240 & 152 & 81 & 48 & 40 \\
HBsAg & - & - & - & - & - & - \\
\hline
\end{tabular}

SGPT= Serum Glutamic Pyruvate Transaminase in international unit, HBsAg= Hepatitis B Surface Antigen $(-)=$ Negative .

\section{Discussion}

In our observation in this short series female was a bit more affected than the male which corresponds with the study by Mamoon ABA \& et. $\mathrm{al}^{10}$. This might be because females were more exposed as they remain in the house most of the time day \& night in our context. 4-10 years of age was the most vulnerable age in our report. It had been seen in India, The peak age of the disease was 5 -9years ${ }^{11}$. This was almost similar to our observations. The important clinical features are generally similar in different geographic regions like chronic fever, hepato- 
splenomegaly, Anaemia, emaciation ${ }^{1}$. Jaundice of different degree was observed in this series in addition to the usual clinical presentations. Accordingly initial clinical diagnosis of chronic liver disease (CLD) was made in significant number of case which is misleading. Raised serum Bilirubin and SGPT was observed among all the cases. These events might be due to hepatitis caused directly by protozoa (LD bodies) itself or indirectly by the effect related to the immunological response of the parasites. In this area, kala-azar is a disease which has jaundice including other features rather than the disease in endemic form in the northern part of Bangladesh. Leucopenia with relative lymphocytosis was marked in kala-azar ${ }^{11}$. This was not similar to our experience. Majority of the patients in our series did not show these investigation findings. This chronic infection might not have any influence in the usual inflammatory response of disease.

In presence of jaundice and absence of leucopenia and relative lymphocytosis might be misleading events for the diagnosis of the kala-azar.

So, In conclusion, it is to be mentioned that the jaundice with other consistent clinical features should not always necessarily be considered as other diagnosis.

Whether Jaundice is to be considered further as a unusual presentation or as a usual presenting features of kala-azar in some parts of the world needs to be vividly studied!

\section{References:}

1. David J. W., Davidson H.H. Leishmaniasis. In : waldo NE, Klegman RM(editors). In: Nelson Textbook of pediatrics, $15^{\text {th }}$ ed. Bangalore. WB saunders. 1996: 972-74.
2. Park K. In: Park's Textbook of preventive and social Medicine $16^{\text {th }}$ edn. 2000. M/S Branarsidas Bhanot publisher, Jabalpur India: 223-233.

3. T.K. Jha, Shayam sundar, Thakur, Bachmann peter, Juntra kabwang, Chri's Fisher. AndresVoss et. al. Multefasine an oral agent for the treatment of Indian Visceral leishmaniasn. New Engl J Med. 1999; 341: 1795-99.

4. Desjenx P. Human Leishmaniasis. Epidemiology and public aspects. World Health statistics Quartile 1992; 45(2/3): 167-275.

5. Alam MN, Chowdhury MAJ, Rafiqueuddin AKM, et al, Kala-azar in bangladesh. Bangladesh $\mathrm{J}$ of Medicine 1990; 1: 5-8.

6. Masum MA, Alam B, Ahemd RU. Kala-azar out break in dinajpur district of Bangladesh. The Hygeia 1990; 4: 122-4.

7. Marinkelle C.J. The control of leishmaniasis. Bulletin of the world Health Organization, 1980. 58-807.

8. Chartterjee K.D. In: Parasitology (Protozology and Helminthology) $12^{\text {th }}$ edition, 1980: 52-60.

9. Mamoon ABA, Chowdhury ZA, Jahan K, et. al. Seroprevalence of kala-azar and its clinical presentation in a rural community of Bangladesh. The Orion 2005; 22: 291-93.

10. World Health Organization (WHO). Technical Report Series No 701, 1984. The leishmaniasis, report of expert committee: 1-36

11. D.H. Smith. Visceral leishmaniasis (Kala-azar) In: Campbell AGM McIntosh N. (editor) Forfar \& Areil's Text book of pediatrics $5^{\text {th }}$ ed. Great Britain: Churchill Livingstone 1998; 1461-63. 